\title{
The Effect of Characteristics, Incumbent Status and Political Party Affiliation of Local Head on Local Expenditure Deviation
}

\author{
Rika Restiana, Abdul Hadi Sirat dan Hartaty Hadady \\ Study Program of Management, Concentration of Local Financial Management, \\ Khairun University, Ternate
}

\begin{abstract}
This research aims to examine the effect of characteristics, incumbent status and political party affiliation of local head on local expenditure deviation. The independent variables are age, education level, professional background, incumbent status and political party affiliation of local heads. The dependent variable is local expenditure deviation. The population is all local heads in Indonesia in 2018. The study samples are 157 Local heads. The sampling method used is purposive sampling technique. The data analysis method is multiple regression facilitated by SPSS version 26 software. The research results show that age, education level, professional background, and incumbent status of local head do not affect on local expenditure deviation. The political party affiliation of local head has a positive effect on local expenditure deviation.
\end{abstract}

Keywords:Characteristics of Local heads, Incumbent Status, Political Party Affiliation, Local Expenditure Deviation

DOI: $10.7176 / \mathrm{PPAR} / 11-6-07$

Publication date:July $31^{\text {st }} 2021$

\section{INTRODUCTION}

The local autonomy system in Indonesia gives some of authority that previously decided by central government. Local autonomy gives local government authority to make local decision. The local autonomy is an embodiment of decentralization to give local the authority to regulate and manage the interests of local community in according to their own initiatives based on aspirations of people (Law Number 32 year 2004 which has been changed to Law no. 23 year 2014).

Upper echelon theory is a theory to explain that organizational outcomes, namely strategic choices and performance levels can be partially predicted by the characteristics of managerial background (Hambrick and Manson 1984). This theory can be adopted in local government where local autonomy and decentralization have made local heads have great authority to manage the local finances.

The corruption in Indonesia has increased since the enactment of decentralization for local governments. The decentralization policy based on Law Number 32 Year 2004 no longer refers to term level because the relationship between provinces and regions is coordinated and independent. The distribution of functions is given to provinces and districts/cities.

The fraud triangle describes the 3 conditions to cause asset deviation and fraud in financial statements. The components of fraud triangle developed by Cressey (1973) are (1) Pressure; (2) Rationalization and (3) Opportunity. The local head has a great opportunity to commit fraud because of opportunity.

Data from Corruption Eradication Commission (KPK) in 2016 to 2019 shows 61 local heads involved in corruption cases with details 10 local heads cases i n2016, 10 local heads cases in 2017, 29 local heads cases in 2018 and 12 local heads cases in 2019.

The report of Supreme Audit Agency of Indonesia Republic (BPK RI) on 157 regions becomes samples for this study. The deviation level of local expenditure in 2017 (the year before the 2018 local elections) was high, with an average value of IDR 4.6 billion.

The factors to affect local expenditure deviation are characteristics of local heads (Yusup and Aryani, 2015). It is the only study that examining the effect of local head characteristics on local expenditure deviation, which is specified in indications of capital expenditure corruption. The characteristics of local heads as independent variables consist of five elements, namely: 1) Incumbent status, 2) education level, 3) educational background, 4) age, and 5) political party affiliation. Based on above background, this research examines the effect of age, level education, professional background, incumbent status and political party affiliation of local heads affect local expenditure deviation.

\section{LITERATURE REVIEW}

Fraud Triangle Theory

The fraud triangle describes three conditions to cause asset misappropriation and fraud in financial statements. The components of fraud triangle are (1) Pressure; (2) Justification (Rationalize); and (3) Opportunity (Cressey, 1973)

Fraud in procurement of goods/services can be caused by the actors are under pressure from superiors or 
other parties who need money from project tender through inappropriate process. The superiors or other parties may give pressure to the actors in order to recover the substantial political costs during the election.

Among the three categories of fraud triangle, opportunity is most likely to be minimized through the application of processes, procedures, and controls in an effort to detect fraud earlier. The opportunity to make fraud is the part that will never fully vanish. Even this opportunity is sometimes deliberately created through the planning system done by leadership, such as when preparing the budget plan (APBN/APBD) by DPR/DPRD.

\section{Upper Echelon Theory}

Upper echelon explains that organizational outcomes, namely strategic choices and performance levels, can be partially predicted through the characteristics of managerial background (Hambrick and Manson 1984). The process of corporate or organizational strategy cannot be separated from individual involvement in organization. The value and cognitive affect on individuals within organization. The top manager plays a major role in determining organizational outcomes. This can be investigated empirically.

\section{Characteristics}

Soemarno Soedarsono (2009) explained character as a value that has been imprinted in a person through experience, education, sacrifice, experimentation, and environmental effects. These are combined with values within a person and become intrinsic values that are manifested in spirit system which underlies a person's attitudes, behavior and thoughts.

\section{Incumbent Status}

Indonesian Dictionary explains the detainee incumbent as position/dignity, while endurance means sitting/remaining. So the incumbent can be interpreted as a person who has the current position.

\section{Political party affiliation}

Big Indonesian Dictionary defines affiliation as a relationship in member or branch or relationship. The affiliation means to have ties and relation as members or branches. Therefore, political party affiliation means to have ties or relationships with political party.

\section{Deviation}

Bruce J. Cohen (1992) said that deviant behavior is any behavior that cannot adapt to wishes of society or certain groups in society. Gillin (1950) explained that deviant behavior deviates from norms and social values of family and society which causes the waning of group bonds or solidarity. Judging from definition of deviation, a simple sentence can be drawn about what deviation is an action to violate certain norms and rules.

\section{Local Expenditure}

Domestic Minister Regulation Number 13 year 2006 amended by Domestic Minister Regulation Number 21 year 2011 explained Local Expenditures as the obligations of local governments as deductions from net assets value. This was estimation of the regional expenditure burden allocated fairly and evenly to be enjoyed by all community groups without discrimination, especially in the provision of public services. Furthermore, local expenditure is divided into categories below.

1) Employee Shopping

2) Goods and services expenditure

3) Interest expenditure

4) Subsidy expenditure

5) Grant expenditure

6) Social aid expenditure

7) Capital expenditure

8) Financial aid expenditures; and

9) Transfer expenditure

\section{Local Expenditure Deviation}

Local expenditure deviation is local expenditure irregularities, namely behaviors that violate the rules regarding local expenditures regulated in provisions of applicable laws. It can harm the region.

\section{Research Framework and Variables Relationships}

The local head is the top leader in an entity consisting of regencies, cities and provinces. The holder of local financial management authority is the local head with who because of his position has the authority to do the overall local financial management. 
The local head characteristics in Indonesia differ widely in terms of age, professional background, education level, political party affiliation and others. The law regulates only the age above 25 years for mayors or regents and 30 years for governors, the minimum education level is high school. In addition, law requires local head candidates affiliated with political party or independent candidates with a minimum requirement of $6.5 \%$ to $10 \%$ support from total Permanent Voter Data (DPT). This has an impact on number of candidates for local heads.

This creates difference in financial management style at each region. One indicator to see the results of local financial management in each region is the examination results of Supreme Audit Agency of Indonesia Republic (BPK RI). BPK finds different result in materiality, ranging from low, medium, and high. In addition, BPK's findings may differ in materiality from year to year in one local government. This can be triggered by condition of local head, including the incumbent local head who will nominate again for a second term of government 5 years later, or the local head whose the term of office will expire.

Based on above description, figure 1 shows the relationship between the characteristics of the regional head, which includes age, education level, professional background, political party affiliation and incumbent status, on regional expenditure deviation.

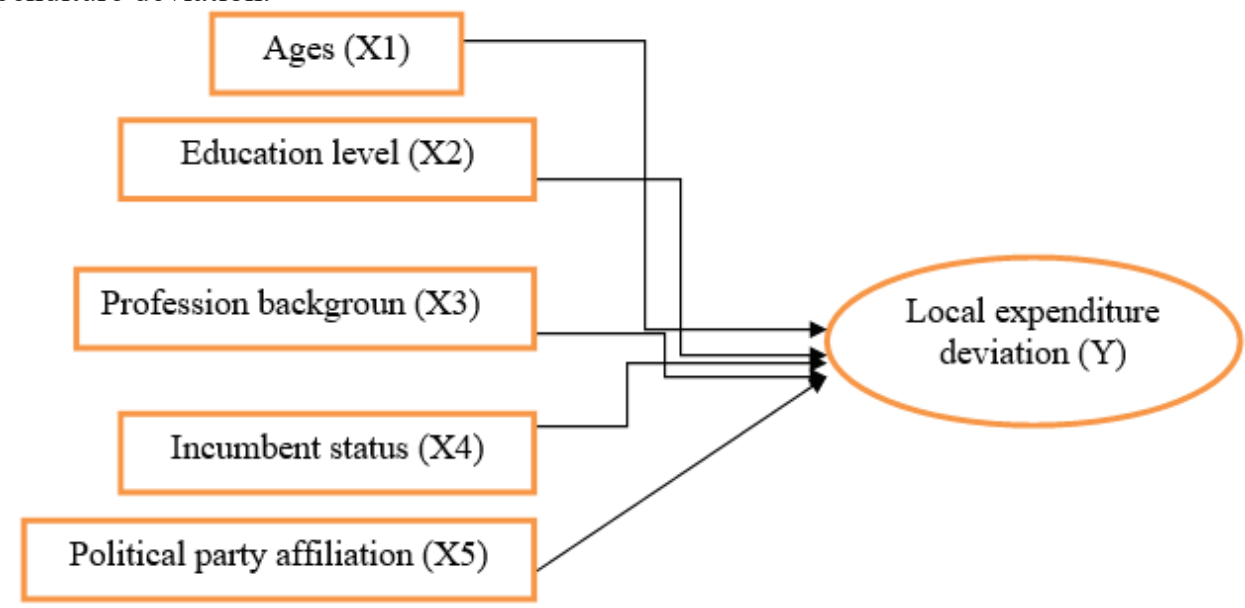

Figure 1. Research Framework

\section{Hypothesis Development}

Zahra et al. (2005) stated that younger people prefer to take risks and low inability to refuse gratification. Older age tends to avoid involvement with crime (Mocan, 2008, in Yusup and Aryani, 2015). Troy et al. (2011) Yusup and Aryani (2015) stated that an older leader has the ability to develop knowledge in making decisions and more difficult to justify fraudulent actions than younger leaders. Yusup and Aryani (2015) showed that age of local head has a negative effect on indications of corruption in local expenditure. Therefore, hypothesis 1 is stated below.

H1: Younger local head will increase the local expenditure deviation.

Yusup and Aryani (2015) showed that education level of local heads has a positive effect on corruption indications in local expenditure. This is consistent with Pahlevi and Setiawan (2017) that education level has a negative effect on local government performance, which means it has a positive effect on local expenditure deviations.

There is a research gap in this variable in similar studies (Prasetyo, 2014; Pratiwi and Aryani, 2016; Mahardani, 2014; Misdi, 2015), where the education level has a positive effect on local government performance, which means it has a negative effect on local expenditure deviation. Therefore hypothesis 2 is stated below.

$\mathrm{H} 2$ : Higher education level of local head will increase the local expenditure deviation.

Profession background is a new variabel in this study, based on a proposal Yusup and Aryani (2015). The professional background of local heads varies because they are not regulated by local election Law. Professional backgrounds such as businessmen, academics, practitioners, bureaucrats, politicians, and others have the potential to affect the leadership style of local heads. Therefore hypothesis 3 is stated below.

H3 : Professional background as politician of local head will increase the local expenditure deviations.

Incumbent status is the condition a person who still holds power in a certain position. Prasetyo (2014) in Yusup and Aryani (2015) showed that longer tenure of local heads may create opportunistic behavior and tend to prioritize their personal and group interests. Based on agency theory, local head as the agent has more information about government management when compared to people as the principal. This information asymmetry opens up opportunities for local heads to use the budget for personal interests (Andvig et al., 2001, in Yusup and Aryani, 2015). In addition, longer tenure makes local heads understand the system loopholes that can 
be exploited for their personal interests. Therefore, hypothesis 4 is stated below.

H4 : Incumbent status of local heads will increase the local expenditure deviation

One direct causes of the corruption is the local heads obligation as members or parties supported by political party to finance political party. Political party have a role in local heads corruption. Local heads affiliated with political party must provide a budget for their political activities. The Yusup and Aryani (2015) showed that political party affiliation of local heads has a positive effect on indications of capital expenditure deviation where the fewer political party affiliations will increase the level of capital expenditure deviation. Therefore hypothesis 5 is stated below.

H5: Fewer political party affiliations will increase the local expenditure deviation.

\section{RESEARCH METHODS}

\section{Population and sample}

This study uses a causal research design to examine the phenomena and to explore factual information to explain the effect of regional heads characteristics, political party affiliation, and incumbent status on regional spending irregularities. The approach used in this research is a quantitative. This research was conducted in Indonesia. The research time was from September to November 2020.

The ordinal secondary data is collected for the independent variable (X1-X5) and the dependent variable (Y). The data was obtained from the data of each regional head and the BPK Audit Report of the Regional Government Financial Reports and Audits with Specific Purposes for the 2017 fiscal year.

The study population is regional heads in regencies/cities/provinces throughout Indonesia, totaling 518, consisting of 416 regencies, 68 cities, and 34 provinces. The samples are selected by purposive sampling method with following criteria:

1. Head of Regency/City/Province in Indonesia whose the local head was incumbent in the 2018 local election.

2. Local heads whose term of office expires in 2018.

3. Local heads that have deviation value.

Based on the above criteria, the total samples are 157 local head

\section{Data analysis}

The data obtained will be analyzed using multiple regression analysis. Therefore, classical assumptions must be met, including normality test, multicollinearity test, and heteroscedasticity test. Multicollinearity test is used to detect symptoms of correlation between one independent variable and another independent variable. Multicollinearity test can be done by looking at Variance Inflation Factors (VIF) and tolerance value. If VIF $>10$ and tolerance value $<0.10$, then multicollinearity symptoms occur (Ghozali, 2014).

The heteroscedasticity test aims to examine the inequality of residual variance from observations to other observations, it is called homoscedasticity. Heteroscedasticity can be tested through the Glesjer test. If the significance probability of each independent variable is $>0.05$, then it is concluded that there is no heteroscedasticity in regression model. The normality test was done with distribution of data. The data is said to be normal if the distribution is around the diagonal line (Ghozali, 2014). After all classical assumptions are met, multiple regression analysis is performed to determine the effect of independent variables on dependent variable.

The determination coefficient is used to measure the model's ability to explain variations in dependent variable (Ghozali, 2014). The F test is used to determine the simultaneous effect of independent variables on dependent variable. The test criteria used are if the probability value $(p$-value $)<0.05$, then the hypotheses is accepted. 


\section{Variables operational definition}

\begin{tabular}{|c|c|c|c|}
\hline No & Variabel & Definition & Measurement \\
\hline 1 & Age (X1) & $\begin{array}{l}\text { The time unit to describe the } \\
\text { length of life/existence of } \\
\text { someone/something }\end{array}$ & $\begin{array}{l}\text { The age of the local head in } 2018 \text { is expressed in } \\
\text { years, } \\
\text { This measurement refers to Yusuf and } \\
\text { Aryani (2015) }\end{array}$ \\
\hline 2 & $\begin{array}{l}\text { Education } \\
\text { level } \\
\text { (X 2) }\end{array}$ & $\begin{array}{l}\text { The education level taken by } \\
\text { the local head }\end{array}$ & $\begin{array}{l}\text { The level of education taken by the local head } \\
\text { The education level of Senior High School and } \\
\text { Medium experts is given } 1 \text { score, the first strata is } \\
\text { given } 2 \text { score, the second strata is given } 3 \text { score, the } \\
\text { third strata is given } 4 \text { score. } \\
\text { This measurement refers to Yusuf and Aryani (2015) }\end{array}$ \\
\hline 3 & $\begin{array}{l}\text { Professional } \\
\text { background } \\
\text { (X 3) }\end{array}$ & $\begin{array}{l}\text { Profession before serving as } \\
\text { local head }\end{array}$ & $\begin{array}{l}\text { Academics (score 1), politicians (score 2), Entrepreneurs } \\
\text { (score 3), bureaucrats (score 4), others (score 5) }\end{array}$ \\
\hline 4 & $\begin{array}{l}\text { Incumbent } \\
\text { status }(\mathrm{X} 4)\end{array}$ & $\begin{array}{l}\text { someone who is still in a } \\
\text { certain position }\end{array}$ & $\begin{array}{l}\text { The dummy variable is measured by number } 1 \\
\text { for incumbent local heads and } 0 \text { for non incumbent } \\
\text { local heads. } \\
\text { This measurement refers to Yusuf and Aryani (2015) }\end{array}$ \\
\hline 5 & $\begin{array}{l}\text { Political party } \\
\text { affiliation } \\
\text { (X5) }\end{array}$ & $\begin{array}{l}\text { The support from political } \\
\text { parties for someone to increase } \\
\text { the opportunity to become a } \\
\text { local head candidate in the } \\
\text { local head election }\end{array}$ & $\begin{array}{l}\text { Local heads who uses individual channel are given } 5 \\
\text { score, local heads who have affiliation with local political } \\
\text { parties are given } 4 \text { score, local heads who have affiliation } \\
\text { with national political parties of not government } \\
\text { coalitions are given } 3 \text { score, local heads who have } \\
\text { affiliation with a government coalition national political } \\
\text { party are given } 2 \text { score, local heads who have affiliation } \\
\text { with more than one coalition and non-government } \\
\text { coalition of national political party are given a score of } \\
\text { (1) } \\
\text { This measurement refers Yusuf and Aryani (2015) }\end{array}$ \\
\hline 6 & $\begin{array}{l}\text { Local } \\
\text { expenditure } \\
\text { deviation }(\mathrm{Y})\end{array}$ & $\begin{array}{l}\text { behaviors that violate the } \\
\text { rules regarding local } \\
\text { expenditures regulated in the } \\
\text { provisions of applicable laws } \\
\text { and it can harm the region. }\end{array}$ & $\begin{array}{l}\text { Local expenditure deviation is the amount of deviation } \\
\text { that occurred in } 2017 \text { (the year before the } 2018 \text { local } \\
\text { election) based on the BPK LHP category of local losses } \\
\text { finding and potential local losses and expressed in rupiah. } \\
\text { This measurement refers Yusuf and Aryani (2015) }\end{array}$ \\
\hline
\end{tabular}

\section{RESEARCH RESULTS}

Classic assumption test

The first classic assumption test is multicollinearity test. The results of multicollinearity test are shown in table 1 .

Table 1. Multicollinearity Test

\begin{tabular}{|c|c|c|c|}
\hline \multirow{2}{*}{\multicolumn{2}{|c|}{ Model }} & \multicolumn{2}{|c|}{ Collinearity Statistics } \\
\hline & & \multirow[t]{2}{*}{ Tolerance } & \multirow[t]{2}{*}{ VIF } \\
\hline \multirow[t]{6}{*}{1} & (Constant) & & \\
\hline & X1. Age & .820 & 1.220 \\
\hline & X2. Education level & .973 & 1.027 \\
\hline & X3. Professional background & .900 & 1.111 \\
\hline & X4. Incumbent status & .838 & 1.193 \\
\hline & X5. Political party affiliation & .975 & 1.026 \\
\hline
\end{tabular}

Source: Secondary data processed, 2020.

Table 1shows that tolerance and VIF values have a narrow range, from 0.820 to 1.220 . It means multicollinearity is not detected. Furthermore, VIF value is less than 10 and tolerance value is more than 0.01 , it means there is no multicollinearity.

The heteroscedasticity test aims to test inequality of residual variance from observations to other 
observations, or it is called homoscedasticity. The test results show that dots spread above and below zero and do not create a certain pattern. Therefore, it means the data do not show heteroscedasticity and further analysis can be done.

The last is the normality test. The test results show that data spreads around the diagonal line and follows the direction of diagonal line. Therefore the regression model satisfies the assumption of normality

The next test is

\section{Simultaneous Test}

The $\mathrm{F}$ test was done to see whether all the independent variables simultaneously had an effect on dependent variable or not. With a level of confidence for hypothesis testing is $95 \%$ or $(\alpha)=5 \%(0: 05)$. The results of $\mathrm{F}$ test can be seen in table 2 .

Table 2. F Test Results

\begin{tabular}{|c|c|c|c|c|c|}
\hline \multirow[b]{2}{*}{ Model } & \multicolumn{5}{|c|}{ Change Statistics } \\
\hline & R Square Change & F Change & df1 & $\mathrm{df} 2$ & Sig. F Change \\
\hline 1 & .084 & 2.757 & 5 & 151 & .021 \\
\hline
\end{tabular}

Source: Secondary data processed by research in 2021

Table 2 shows that together there is a positive effect between the independent variables on dependent variable. In results of regression test in this study, it is known that F test is 2.757 with a significance level of 0.021 , which requires a significant $\mathrm{F}$ value less than 0.05 . This means that regression model on effect of Characteristics, Incumbent Status, and Political Party Affiliation of Local head on level of deviation is significant. This shows that simultaneously the variables of Characteristics, Incumbent Status, and Affiliation of Local head Political party local expenditure deviation. And it can be concluded that regression model built in this study is declared feasible.

The R square shows 0,85 or $8,5 \%$. It means that the simultaneous effect of can be explained by Local head characteristic, Incumbent Status, and Political party affiliation at $8.4 \%$, while the rest $91.6 \%$ is explained by other variables outside the model.

\section{Hypothesis Testing}

Hypothesis testing was done by looking at the t-statistics and Sig-level in multiple regression analysis which analyzed using SPSS Version 26. The t-statistic value indicates the nature of the relationship between constructs (positive or negative), while the Sig-level indicates the level of significance. The test results are shown in table 3.

\begin{tabular}{l|r|r|r|}
\multicolumn{1}{c}{ Variable 3. Multiple Regression analysis results } & information \\
\hline (Constant) & \multicolumn{1}{c}{ Sig. } & Rejected \\
\hline Age (X1) & 9.594 & 0.008 & Rejected \\
\hline Education Level (X2 ) & -0.058 & 0.954 & Rejected \\
\hline Profession (X3 ) & 1.208 & 0.229 & Rejected \\
\hline Incumbent (X4 ) & -1.692 & 0.093 & Accepted \\
\hline Affiliated Political party (X5 ) & -0.210 & 0.834 & 0.004 \\
\hline
\end{tabular}

source: Data secondary processed, 2020.

The t-tests use significance level of $5 \%$ or 0.05 . The hypothesis is supported if the t-values are greater than the t-table values. The t-table value is 1.660 for a significance of 0.05 . The descriptions of hypothesis test results are explained below.

a. Age (X1)

The relationship between the age of regional heads and regional expenditure deviations is not significant at $t$ values of $-0.058(<1.66023)$ with a significance of $0.954(>0.05)$, then the direction of the relationship between the age of regional heads and regional expenditure deviations is negative but not significant. It means the hypothesis $\mathrm{H} 1$ is rejected.

b. Education Level (X2)

The relationship between the education level of regional heads and regional expenditure deviations is not significant at $t$-values of $1.208(<1.66023)$ with a significance of $0.388(>0.05)$. The direction of the relationship between the education level of regional heads and regional expenditure deviations is positive but not significant. It means the hypothesis $\mathrm{H} 2$ is rejected.

\section{c. Professional Background (X3)}

The relationship between the professional background of regional head and regional expenditure deviations is not significant with $t$-values of $-1,692(>1.66023)$ with a significance of $0.461(>0.05)$. The direction of the relationship between the regional head's professional background and regional expenditure deviations is negative 
but not significant. It means the hypothesis H3 is rejected.

\section{d. Incumbent Status (X4)}

The relationship between the incumbent status of regional heads and regional expenditure deviations is not significant with T-values of $-0.210(<1.66023)$ at a significance level of $0.464(>0.05)$. The direction of the relationship between the status of incumbent regional heads and regional expenditure deviations is negative but not significant. It means the hypothesis $\mathrm{H} 4$ is rejected.

\section{e. Political Party Affiliation (X5)}

The relationship between the political party affiliation of the regional head and regional expenditure deviations is significant with t-values of $2.893(<1.66023)$ with a significance of $0.008(<0.05)$. The direction of relationship between the Affiliation of Regional Head Political party with Regional Expenditure Deviations is positive and significant.

\section{DISCUSSION}

The test results of $\mathrm{X} 1$ to $\mathrm{X} 4$ on $\mathrm{Y}$ are inconsistent with previous studies. The test result of $\mathrm{X} 5$ on $\mathrm{Y}$ is consistent with previous studies. This difference is not only caused by differences in sample and time of study, but also due to Indonesia's changing conditions in dealing with corruption.

The theoretical basis explained that components of fraud triangle were (1) Pressure; (2) Rationalization and (3) Opportunity (Cressey, 1973). One elements of fraud is justification. The fraud triangle theory explains that rationalization encourage someone to commit fraud. Rationalization is the most widely used as an excuse to commit situational fraud, as in example below.

- "I'm only borrowing they money; I'll pay it back". Perpetrators assume that they are only borrowing stolen assets

- "Everyone does it". Actions are done by many people together so that they are considered common and these actions are considered not to harm anyone.

The punishment for corruptors in Indonesia handled by KPK decreased from 2014 to 2020. it makes the corruption cases cannot be processed by law enforcement officers, such as the BLBI case that cost the state trillions rupiah, which the main perpetrator only sentenced 2 years. This was seen as an opportunity for the authorities to commit fraud.

The average value of local expenditure deviation obtained from data tabulation is IDR 4.6 billion. This value is a significant for deviations in one budget year. This shows that variations in characteristics of a local head have the same opportunity to make deviations. This can be seen from local heads as targets of KPK operations have increased from 2016 to 2019, which reached 61 people with different characteristics.

The justification of "Everyone does it" is appropriate in describing the situation of local financial management in Indonesia, where the tendency of local heads of various characteristics can deviate local expenditures.

\section{The Effect of Age of Local heads on Local Expenditure Deviation}

The direction of relationship between the age of local head and local expenditure deviations is also negative, but the effect is not significant. This result is in line with research of Yusup and Ariyani (2015) which shows that age has a negative effect on local expenditure deviations. The description of relationship between the X1 variable (Age) and Y variable can be seen in following diagram.

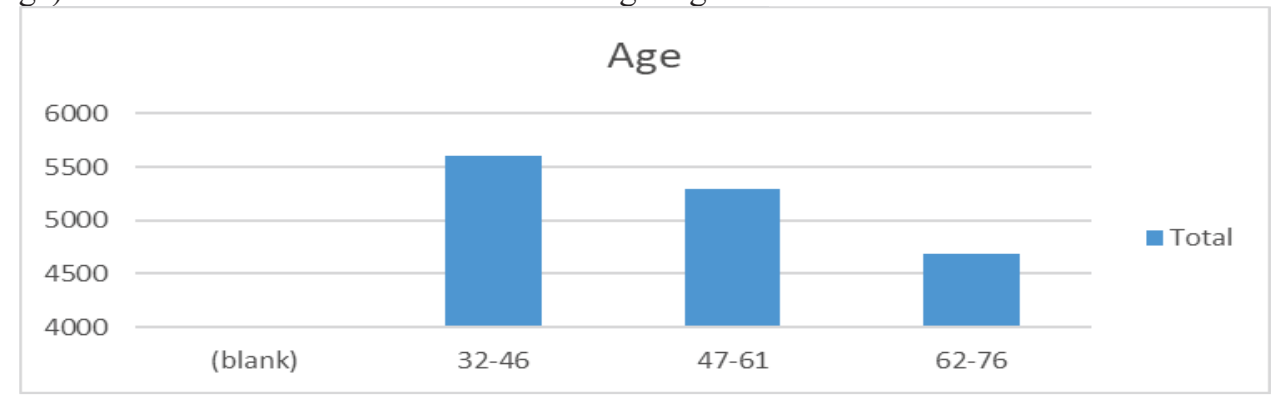

Above diagram shows that younger Local head has higher the level of deviation. However, because the range is not high, relationship between $\mathrm{X} 1$ and $\mathrm{Y}$ the results are insignificant.

\section{The Effect of Education Level of Local heads on Local Expenditure Deviations}

The direction of relationship between the education level of local head and local expenditure deviations in this study is also positive, but insignificant. This result is in line with research of Yusup and Ariyani (2015) that education level has no significant effect on local expenditure deviations. The description of relationship between $\mathrm{X} 2$ (Education Level) and Y variable can be seen in following diagram. 


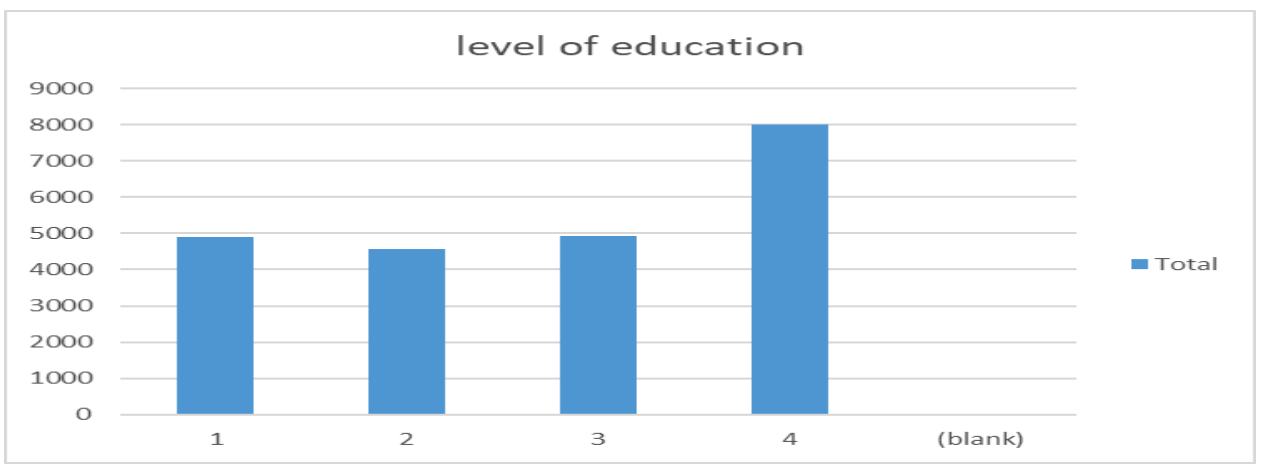

Above diagram shows that largest deviation is at Strata 3 education level, but the lowest is at Strata 1 education level, so that direction of relationship is positive but not significant because the distribution of average deviation level for 4 education level criteria does not show a consistent increase from 1 up to 4.

The Effect of Local head's Professional Background on Local Expenditure Deviations

The description of relationship between X3 (Professional Background) and Y Variable can be seen in following diagram.

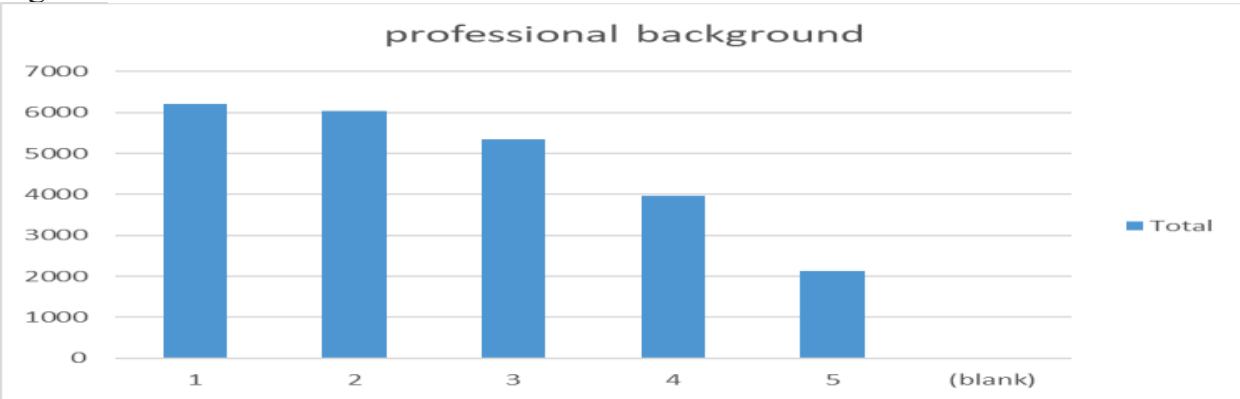

Above diagram shows that professional background number 1 is academics and number 2 is politicians who have a high deviation value compared to professional backgrounds of bureaucrats, entrepreneurs, and others. However, because the range is not high, correlation between X3 and Y after processing using SPSS shows insignificant results. This result is inconsistent with Zahra et al. (2007) that professional background has a significant effect on irregularities committed by officials..

\section{The Effect of Incumbent Status of Local head on Local Expenditure Deviations}

The direction of relationship between the incumbent status of local head and local expenditure deviations in study was negative and effect was not significant. This result is inconsistent with Yusup and Ariyani (2015) which shows that incumbent's status has a significant effect on local expenditure deviation. This shows a shift in conditions where previous research has a positive direction of relationship between these variables. The description of relationship between X4 variable (Incumbent status) and Y variable can be seen in following diagram.

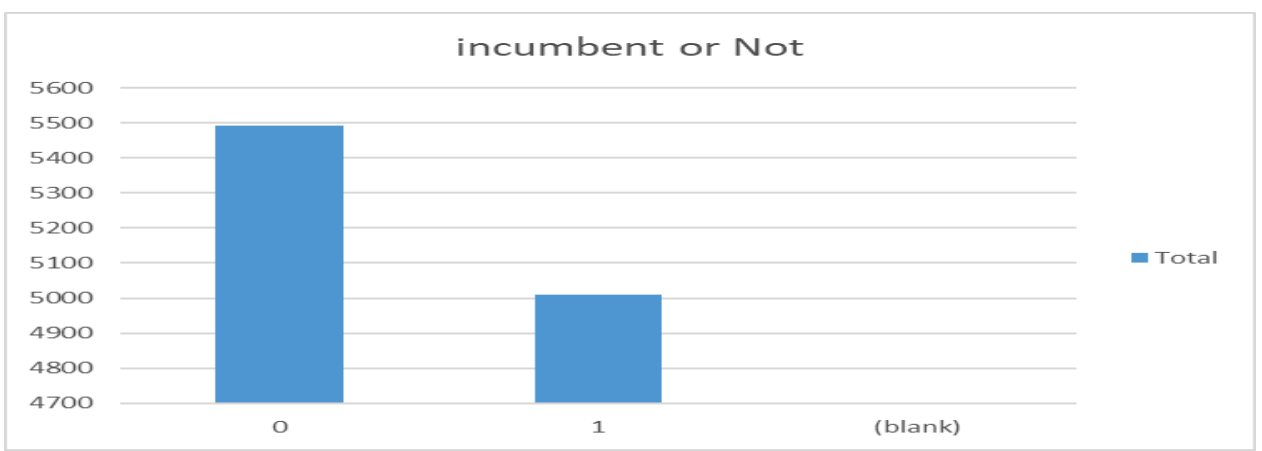

Above diagram above shows that average level of deviation in local expenditures for non-incumbent local heads, which are at end of their term of office, is higher than the average deviation rate for local heads with incumbent status, although at an insignificant level.

\section{The Effect Political party Affiliation of Local head on Local Expenditure Deviations}

The relationship between local heads' political party affiliations with local expenditure irregularities in this study is significant. This result is consistent with Yusup and Ariyani (2015) that political affiliation has a 
significant effect on local expenditure deviation. This shows that political party affiliation of local heads consistently effects local expenditure deviation, even though there are differences in political and government conditions in Indonesia. The description of relationship between X5 (Political Party Affiliation) and Y Variable can be seen in following diagram.

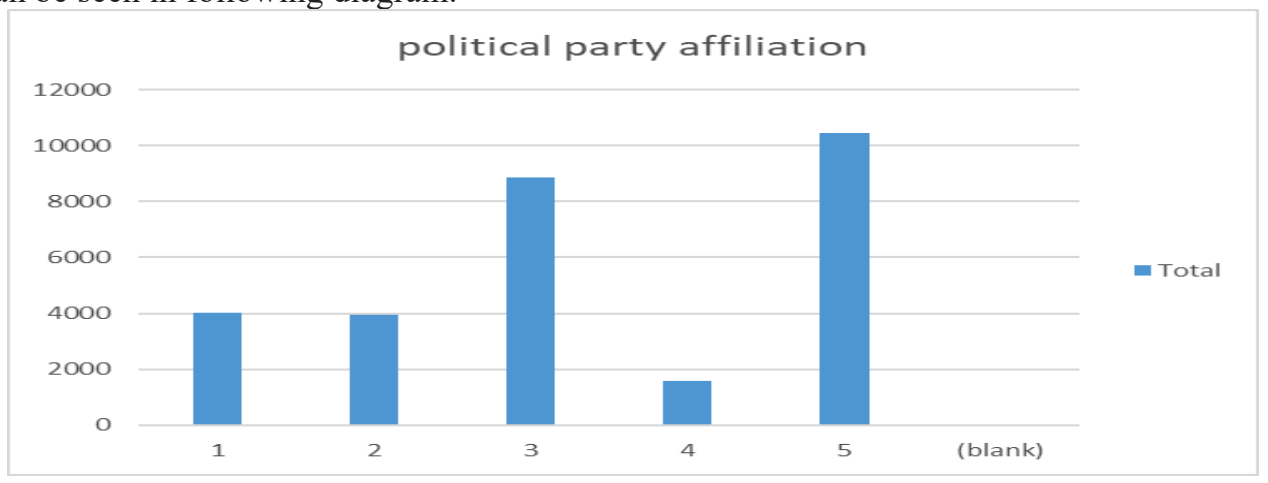

\section{CONCLUSION}

Based on the research result, the conclusions can be stated below.

1. The age of local head cannot become a predictor for local expenditure deviation. The statistical test shows the negative relationship between the two variables (X1 and Y).

2. The education level of local head cannot become a predictor for local expenditure deviation. Statistic tests show a positive relationship between the two variables (X2 and Y).

3. The professional background of local head cannot become a predictor of local expenditure deviation. Statistical tests show the negative relationship between the two variables (X3 and Y).

4. Incumbent status of local head cannot become a predictor for local expenditure deviation. The statistical tests show the negative relationship between the two variables (X4 and Y).

5. The political party affiliation of local head has a positive effect on local expenditure deviation. This means that local heads from independent channels tend to have higher levels of local expenditure deviation.

Based on the research findings and the conclusions, the suggestion can be stated below.

1. The government's external auditor can use this study results regarding on the political party affiliation of local head in determining the audit focus.

2. This study uses multiple regression analysis which only examines the direct effect of independent variable on dependent variable. Therefore, future research should develop this research to test the moderation effect with adding "WTO chief response" variable to strengthen or weaken the relationship of X variables on Y variable. It is because Permendagri 13 year 2006 on local financial management and the amendments stated that OPD head is the budget user to implement the local budget. In addition, the independen variables can also be added with Integrity, Independence, and professionalism of government external auditors variables. This is based on reason that BPK's audit results difference depend on level of integrity, independence, and professionalism of each auditor.

\section{REFERENCES}

Peraturan BPK Nomor 5/K/I-XIII.2/8/2010, Petunjuk Teknis Kodering Temuan Pemeriksaan

Muhamat Yusup Dan Y.Anni Aryani (2015), Karakteristik Kepala Daerah, Afiliasi Partai Politik Dan Indikasi Korupsi Belanja Modal

Shaker A. Zahra, Richard L. Priem Dan Abdul A. Rasheed (2007), Understanding The Causes And Effects Of Top Management Fraud

Agus Prasetyo (2014), Karakteristik Kepala Daerah dan Kinerja Penyelenggaraan Pemerintah daerah di Indonesia

Agus Reza Pahlevi dan Doddy Setiawan (2017), Apakah Karakteristik Kepala Daerah Berdampak Terhadap Kinerja Pemerintahan?

Ristu Pratiwi dan Y Anni Aryani (2016), karakteristik pemerintah daerah, kepala daerah, tindak lanjut temuan audit terhadap opini

Nikke Yusnita mahardani (2014), pengaruh karakteristik kepala daerah terhadap kinerja keuangan pemerintah

Misdi (2015), pengaruh karakteristik kepala daerah terhadap kinerja keuangan daerah

Agus Priyono (2018), Pengaruh Partisipasi Penganggaran, Peran Manajerial Dan Pengawasan Terhadap Kinerja Pemerintah Daerah Dengan Komitmen Organisasi Sebagai Variabel Intervening Pada Pemerintah Provinsi Maluku Utara

Undang Undang nomor 32 Tahun 2004 Tentang Pemerintah Daerah

Arifianti Et. Al, 2013, Pengaruh Pemeriksaan Dan Pengawasan Keuangan Daerah Terhadap Kinerja 
Penyelenggaraan Pemerintahan Daerah (Studi Empiris Pada Pemerintah Kabupaten/Kota Di Indonesia) Hambrick dan Manson (1984), Upper Echelon Theory

Donald R. Cressey, Other People's Money (Montclair: Patterson Smith, 1973)

Hasan, Aliah B. Purwakania. (2008), Psikologi Perkembangan Islami

Kamus Besar Bahasa Indonesia (2008)

Undang-Undang Republik Indonesia Nomor 20 Tahun 2003 Tentang Pendidikan Nasional

Aplikasi Sisdiknas, 2003.

Hasbullah, 2008, Dasar-Dasar Ilmu Pendidikan

Basrowi (2010), Analisis Kondisi Sosial Ekonomi Dan Tingkat Pendidikan Masyarakat Desa Srigading, Kecamatan Labuhan Maringga

Muliani (2009), Faktor-Faktor Dalam. Diri. Auditor Dan Kualitas Audit: Studi Pada Kap 'Big Four' Di. Indonesia

Suhardjo (2007), Berbagai Cara Pendidikan Gizi

Notoatmodjo (2003), Pengembangan Sumber Daya Manusia

Soemarno Soedarsono (2009), Karakter mengantar bangsa dari gelap menuju terang

R Rizal Sisnanto (2009), Etika Profesi

Peraturan Menteri Dalam Negeri Nomor 13 Tahun 2006 Tentang Pengelolaan Keuangan Daerah

Bruce J. Cohen (1992), Sociology

Gillin (1950), Cultural Sociology

Lewis Coser (1989), Sociologist Who Focused On Intellectuals

James Vander Zenden (1977), Social Psychology

Paul B. Horton, Alih Bahasa Tahun 1999, Sosiologi Jilid I

Robert M.Z. Lawang (1997), Pengantar Sosiologi

Undang Undang Nomor 10 Tahun 2016 Tentang Perubahan Kedua Atas UU Nomor 1 Tahun 2015 Tentang Penetapan Peraturan Pemerintah Pengganti UU Nomor 1 Tahun 2014 Tentang pemilihan gubernur, bupati, dan walikota menjadi Undang-Undang 